\title{
Incidence of pressure injury in an adult intensive care unit
}

\author{
Incidência de lesão por pressão em unidade de terapia intensiva para adultos
}

Incidencia de lesión por presión en unidad de terapia intensiva para adultos

Andressa Godões Constantin', Ana Paula Pereira Moreira ${ }^{1}$, João Lucas Campos de Oliveira' Lili Marlene Hofstätter ${ }^{1}$, Luciana Magnani Fernandes ${ }^{1}$

\section{ORCID IDs}

Constantin AG (D) https://orcid.org/0000-0001-7127-9959

Moreira APP (iD https://orcid.org/0000-0003-3122-1685

Oliveira JLC (D) https://orcid.org/0000-0002-1822-2360

Hofstätter LM (D) https://orcid.org/0000-0002-9852-1300

Fernandes LM iD https://orcid.org/0000-0001-5182-6986

\section{HOW TO CITE}

Constantin AG; Moreira APP; Oliveira JLC; Hofstätter LM; Fernandes LM. Incidence of pressure injury in an adult intensive care unit. ESTIMA, Braz. J. Enterostomal Ther., 16: e1118. doi: 10.1030886/ estima.v16.454.

\begin{abstract}
Objective: To identify the incidence of pressure injury (PI) in adults hospitalized in an intensive care, as well as the risk factors and characteristics of their development. Method: Descriptive, prospective and observational research. Between June and September 2016, with a sample ( $n=58$ ) eligible patients, demographic and clinical data were collected, the Braden scale score and intrinsic and extrinsic risk factors, besides having performed the daily observation of the entire surface of the skin regarding the development of PI. From the tabulated data, descriptive statistical analysis was performed. Results: The sample was predominantly men (55.1\%), hospitalized for neurological conditions (32.8\%) and with a very high risk of PI at admission (94.8\%). The incidence of PI was $20.6 \%$, and the sacral region was the most affected by these injuries (76.5\%). Conclusion: The incidence of PI was 20.6\%, in a clientele with a high risk for the development of this adverse event, which mainly affected the sacral region.
\end{abstract}

DESCRIPTORS: Pressure injury; Intensive care units; Patient safety; Nursing care; Stomatherapy

\footnotetext{
${ }^{1}$ Universidade Estadual do Oeste do Paraná - Centro de Ciências Biológicas e da Saúde - Colegiado do Curso de Graduação em Enfermagem - Cascavel/PR - Brazil.

Correspondence author: João Lucas Campos de Oliveira | Universidade Estadual do Oeste do Paraná - Centro de Ciências Biológicas e da Saúde - Colegiado do Curso de Graduação em Enfermagem | Rua Universitária, 2069 - Jardim Universitário | ZIP Code: 858119-110 - Cascavel/PR - Brazil | E-mail: enfjoaolcampos@yahoo.com.br 


\section{RESUMO}

Objetivo: Identificar a incidência de lesão por pressão (LP) em adultos internados em terapia intensiva, bem como os fatores de risco e características do seu desenvolvimento. Método: Pesquisa descritiva, prospectiva e observacional. Entre junho e setembro de 2016, de uma amostra $(n=58)$ elegível de pacientes, procedeu-se a coleta de dados demográficos e clínicos, do escore da escala de Braden e de fatores de risco intrínsecos e extrínsecos, além de ter se realizado a observação diária de toda a superfície da pele quanto ao desenvolvimento de LP. Dos dados tabulados, fez-se análise estatística descritiva. Resultados: A amostra era predominantemente do sexo masculino (55,1\%), internada por condições neurológicas (32,8\%) e com muito alto risco de LP na admissão (94,8\%). A incidência de LP foi de 20,6\%, sendo a região sacral a mais acometida por essas lesões (76,5\%). Conclusão: A incidência de LP foi de 20,6\%, em uma clientela com alto risco para o desenvolvimento deste evento adverso, que acometeu principalmente a região sacral.

DESCRITORES: Lesão por pressão; Unidades de terapia intensiva; Segurança do paciente; Cuidados de enfermagem; Estomaterapia

\section{RESUMEN}

Objetivo: Identificar la incidencia de lesión por presión (LP) en adultos internados en terapia intensiva, así como también los factores de riesgo y características de su desarrollo. Método: Investigación descriptiva, prospectiva y de observación. Entre junio y septiembre de 2016, de una muestra $(n=58)$ elegible de pacientes, se procedió a la recolección de datos demográficos y clínicos, de la puntuación de la escala de Braden y de factores de riesgo intrínsecos y extrínsecos, además de haberse realizado observación diaria de toda la superficie de la piel, así como el desarrollo de LP. De los datos estipulados, se hacen análisis estadísticos descriptivos. Resultados: La muestra era predominantemente de sexo masculino (55,1\%), internado por condiciones neurológicas (32,8 \%) y con muy alto riesgo de LP en la admisión (94,8 \%). La incidencia de LP fue del 20,6 \%, siendo la región del sacro la más aquejada por estas lesiones (76,5\%). Conclusión: La incidencia de LP fue del 20,6 \%, en una clientela con alto riesgo para el desarrollo de este evento adverso, que afectó principalmente la región del sacro.

DESCRIPTORES: Lesión por presión; Unidades de terapia intensiva; Seguridad del paciente; Cuidados de enfermería; Estomaterapia

\section{INTRODUCTION}

In the face of constant social, epidemiological and organizational changes, the quality in the health sector is a phenomenon that is transformed according to the undulations of the needs of man and the market. In this regard, in response to the evolution of care practices and the recognition of risk attached to care, there is no way to dissociate quality in health from patient safety ${ }^{1}$.

The patient safety should be a focus of managerial and assistance actions in health organizations, reflecting in strategies that compromise the individual professional and systemic institutional commitment for the sake of this $\operatorname{good}^{1,2}$. Currently, in Brazil, strategies for patient safety have been recommended, including in the form of action protocols, with emphasis on the following axes: patient identification; safe surgery; hand hygiene; use safety, drugs prescription and administration; communication improvement; and tumbles reduction and pressure injuries $(\mathrm{PI})^{1}$.

The PI is understood as any injury that manifests itself from soft tissue exposure to prolonged tissue pressure, which unleashs damage of varying magnitude, especially in places of bone prominence ${ }^{3}$. Thus, the extent and severity of PI are factors directly related to the time of exposure and the pressure intensity of the injured tissue ${ }^{3,4}$.

The PI can be classified in four stages, which are basically related to the severity/depth of the injury. In this aspect, the gradual evolution of the PI begins with the whole skin, with erythema that does not whiten (Stage I); progresses to skin loss in its partial thickness, with exposure of the dermis (Stage II); the skin loss in its total thickness, in which fat is visible, and often there is tissue granulation and epibole (Stage III); until the skin loss in its total thickness, with direct exposure or palpation of muscle fascia, muscle, tendon, ligament, cartilage and/or bone (Stage IV $)^{5}$. In addition to the depth of the injury, each stage may present its own clinical characteristics ${ }^{3}$.

It should be pointed out that the PI as a classification can still be denominated as an unclassifiable injury, when there is skin loss in its total thickness and tissue loss in which the extent of the damage cannot be confirmed because it is covered by slough or eschar ${ }^{3}$. There is also a deep tissue injury in which the skin may be intact or not, with a localized and persistent area of dark red, brown or purple discoloration that does not whiten or there is epidermal separation that shows injury with darkened bed or bubble with sanguineous exudate ${ }^{3}$. 
Although the PI classification is essentially valid for the planning of its best treatment, it is postulated that knowing the risk factors and the measures of prevention of this adverse event is a fundamental aspect in the elaboration of qualified and individualized care, nurses, who must reaffirm their professional autonomy in these actions $s^{6,7}$. In this context, it is known that the environment of hospitalization in the Intensive Care Unit (ICU) is a place that deserves even more attention in the prevention of PI, since the intrinsic risk factors to the patient hospitalized in ICU and therapeutic diagnostic interventions of intensive care may favor the predisposition to this undesirable event ${ }^{8}$.

The intensive hospital care is a factor of concern for the development of PI due to the patients' own clinical severity, which usually incurs the use of sedatives for mechanical ventilation that favors full immobilization but that realized by the health team, with a focus on nursing; muscle mass loss; and the long average stay at hospitalization ${ }^{7}$. Also, nutritional imbalance, especially in the context of albuminwhich favors cell growth and, consequently, the healing process - is also a risk factor for PI found in $\mathrm{ICU}^{8}$.

Even though the literature has already pointed out more than one hundred PI risk factors, it is postulated that $90 \%$ of these injuries could be prevented with the strict establishment of adequate care ${ }^{4}$. Internationally, recommendations - which vary in their efficacy - for PI prevention care include patient mobilization, with emphasis on controlled decubitus change to a maximum of 2 hours; nutrition and hydration (enteral and topical skin); the use of skin protection materials/devices and minimization of pressure in areas of bone prominence; and the education of professionals and families; among others of a more individualized nature, depending on the clinical conditions of each patient ${ }^{3}$.

In spite of the evolution of the knowledge of risk factors and measures of PI prevention, its incidence - which is an indicator of quality assistance ${ }^{9}$, especially in ICU, has been a persistent problem, and it is still necessary to be used as a research object ${ }^{10-12}$. This is because the incidence of PI is based on the measurement of new cases of the adverse event, that is, it is an epidemiological measure that may favor the (re)planning of care actions with a focus on the rational prevention of new injuries, according to a scientifically situational diagnosis supported ${ }^{9}$.

It is believed that investigating the incidence of PI and its related factors is valuable to the knowledge of the institutional profile, with the possibility of comparing/ benchmarking of the indicator to other realities. In the ICU scenario, this may be even more evident, once the high risk of this care environment is recognized ${ }^{7}$, which requires that epidemiological measures, such as the incidence of PI, be used directly for the best planning of intensive care.

Considering the justification for the scientific studies of the problematic presented, the concern about this research emerged, which was guided by the following question: What is the incidence of PI in a ICU for adults in a university hospital and what are their characteristics and risk factors related?.

\section{OBJECTIVE}

To identify the incidence of PI in adults hospitalized in intensive care, as well as the risk factors and characteristics of their development.

\section{METHOD}

This is a descriptive, cross-sectional, prospective, observational and quantitative approach. The research was realized in the ICU for adults of a public university hospital in the state's countryside of Parana, Brazil. The hospital has 210 active beds exclusively for the Unified Health System (UHS) and is a reference for trauma care, high risk gestation and treatment of human immunodeficiency virus (HIV). In turn, the ICU surveyed has an operational capacity of 14 beds.

The study population consisted of all the patients hospitalized in this ICU from June to September 2016. The sample was composed by patients who accorded the following inclusion criteria: did not present PI at admission to the ICU, remained hospitalized at the unit for no minimum 24 hours and submit at least two assessments of skin condition.

The data collection occurred prospectively, daily, during the established temporal cut. For this purpose, a form, adapted from a previous study instrument ${ }^{13}$ was used to guide the observation of patients, containing the following variables: demographic data (gender and age); clinical data (health problem related to ICU hospitalization and period of hospitalization); intrinsic and extrinsic risk factors for PI 
development; presence of PI, place and stage; and Braden's score on the patient's first and last evaluation.

Due to the range of the risk factors of PI already described, which exceeds the amount of one hundred ${ }^{4}$, its were chosen according to the predetermination of the supporting literature, which determined the following predisposing factors to PI, with the following conditions and/or clinical interventions: diabetes; renal insufficiency; chronic obstructive pulmonary disease (COPD); congestive heart failure; cerebrovascular accident (CVA); use of sedatives and/or vasoactive drugs; and mechanical ventilation ${ }^{13}$.

Regarding the intrinsic risk factors of PI to the patient, turgor and skin elasticity ("wilted" skin and slowly dissolving:> 3 seconds) were observed; smooth, fine or delicate skin; rough skin, presenting pleating; unobtrusive to moderate edema (scale from one "+" to three “+++"); severe edema (“+++" to “+++++”); moist skin; and sepsis. On the other hand, the extrinsic risk factors considered for PI were: traditional hospital bed mattress and bedside elevation $<45$ degrees $^{13}$. The elevation of the bedside between 30 and 45 degrees was considered as protection, as well as observation of air mattress ${ }^{14}$.

The total score varies from 6 to 23 points, very high risk (scores less than or equal to 9), high risk (scores from 10 to 12 points), moderate risk (scores from 13 to 14 ), low risk (scores from 15 to 18 points) and no risk (scores from 19 to 23 point $)^{15}$. In this study, the Braden scale score was described in the first and last observation of each participant patient. In case of death, the scale score repeated that of the last evaluation, so that the patient was not excluded from the sample.

The instrument was filled on the first day of observation/ hospitalization of each patient, which was monitored daily during the data collection period. Each day, in order to attenuate the biases common to observational studies, as recommended ${ }^{2}$, a single researcher inspected the skin of the patients included in the research.

The patient's observation occurred preferably during the bath and/or care of these and occurred mostly in the evening period. The researcher who performed the data collection, nursing academic of the last semester of graduation, was previously trained for this purpose by a nurse, Doctor Professor of the intensive care area and researcher on PI. The docent trained the graduate student to carry out all the data collection and, later, assisted in the description of the discoveries. At any sign of erythema and/or loss of skin thickness, the nurse in the sector and shift was reported in order to take reasonable care of the patient.

All data from observations and forms fillings were transposed into spreadsheets of Microsoft Office Excel ${ }^{\circledR}$ 2010 software. From the tabulated data, descriptive statistical analysis was performed on proportion measures. The PI incidence rate was calculated using the own formula recommended by the Nucleus of Support for Hospital Management $(\mathrm{NSHM})^{16}$, in which only the substitution of the taxonomy "PU" for "PI" was adapted:

Incidence of LP in ICU-Adult $=$ (number of new cases of PI patients in a given period/number of people exposed to the risk of acquiring PI in the period) $\times 100$

The number of new cases was that of patients who developed PI, regardless of the stage or place of the injury identified. According to the proposed method, the incidence occurred on the number of patients with PI, and not on injuries. The number of people exposed to risk for the injury was the total number of patients who participated in the study ${ }^{16}$. That is, the chosen measurement method deals with a calculation of PI incidence in ICU patients, once the proportion of new cases has been compiled on the total number of hospitalized and eligible patients in a given period of time in the same unit $^{9,16}$.

All the ethical precepts governing human research have been done. Regarding this, the research project that fomented this study was submitted to and approved by the Ethics Committee in Research Involving Human Beings of the State University of the West of Parana, under protocol no 571.801/2014 and CAAE: 25175014.7.0000.0107.

\section{RESULTS}

It was participated $58(100 \%)$ patients who were hospitalized in the ICU eligible for inclusion in the study. There were 12 patients lost due to the fact that they entered the unit already presenting PI, and another four, because it was not possible to perform a second skin evaluation, since the discharge occurred prior to the observation visit.

The largest share $(55.1 \%)$ of the sample was men compared to the proportion (44.9\%) of women. The patients' 
ages ranged from 17 to 83 years, with an average of 50 years $(\mathrm{SH}=18.1)$. The mean ICU hospitalization was 18.2 days $(\mathrm{SH}=17.4)$. Table 1 summarizes the discoveries of hospitalization reasons in intensive care, based on medical diagnosis.

The following conditions and/or clinical interventions predisposing to PI were observed: diabetes ( $\mathrm{n}=5,8.6 \%)$, renal insufficiency $(\mathrm{n}=21,36.2 \%), \mathrm{COPD}$, congestive heart failure $(n=10,17.2 \%)$, use of sedatives $(n=49,84.4 \%)$, use of vasoactive drugs $(\mathrm{n}=45 ; 77.5 \%)$ and mechanical ventilation $(\mathrm{n}=53,91.3 \%)$.

On the other hand, the intrinsic PI risk factors to the patient, regarding skin conditions and edema, are shown in Table 2. More than one factor may have been observed in the same patient, so the difference of the total observed in comparison to the number of participants $(n=58)$. However, the relative proportion was calculated on the basis of this total.

Regarding the risk factors (or protection) for PI extrinsic to the patient, the following discoveries were obtained:

Table 1. Frequency of patients' reasons for hospitalization ( $n=58$ ) in the Intensive Care Unit, based on medical diagnosis. Cascavel, Paraná, Brazil, 2016.

\begin{tabular}{ccc} 
Diagnostic base & $\mathbf{n}$ & $\%$ \\
\hline Gastrointestinal & 11 & 18.9 \\
Respiratory & 14 & 24.2 \\
Neurological & 19 & 32.8 \\
\hline Cardiovascular & 3 & 5.2 \\
\hline Trauma & 11 & 18.9 \\
\hline Total & 58 & 100 \\
\hline
\end{tabular}

Table 2. Intrinsic factors observed for the risk of pressure injury, according to skin conditions and edema. Cascavel, Paraná, Brazil, 2016.

\begin{tabular}{ccc}
$\begin{array}{c}\text { Intrinsic risk } \\
\text { factors }\end{array}$ & $\mathbf{n}$ & $\%$ \\
\hline $\begin{array}{c}\text { Decreased turgor and } \\
\text { skin elasticity }\end{array}$ & 17 & 29.3 \\
\hline $\begin{array}{c}\text { Smooth, fine or } \\
\text { delicate skin }\end{array}$ & 34 & 58.6 \\
Rough skin & 19 & 32.7 \\
\hline Unobtrusive edema & 29 & 50.0 \\
\hline Intense edema & 20 & 34.4 \\
\hline Anasarca & 2 & 3.4 \\
\hline Dry skin & 5 & 8.6 \\
\hline
\end{tabular}

presence of traditional hospital mattress associated with air mattress (overlaid) in all $(\mathrm{n}=58 ; 100 \%)$ patients in the evaluations and elevation of the bedside from 30 to 45 degrees $(n=21 ; 36.2 \%)$. No patient presented bedside elevation $>45$ degrees.

Table 3 illustrates the relevant discoveries to the Braden scale score assessed on the first and last day of hospitalization/observation of the patients.

Of the total $(n=58)$ of patients followed up, 12 developed PI. Therefore, the incidence of the adverse event found in the study was $20.6 \%$. Of these, some had more than one injury. The total PI was 17 injuries. In this respect, Table 4 summarizes the PI results presented in relation to the place of involvement and degree/stage of the injury.

Table 3. Patients' Braden scale score $(n=58)$ on the first and last day of hospitalization (DH). Cascavel, Paraná, Brazil, 2016.

\begin{tabular}{cccc} 
Variable & $\begin{array}{c}\text { Categories } \\
\text { (Braden) }\end{array}$ & $\mathbf{n}$ & $\%$ \\
\hline No risk & - & - \\
First DH & Low & - & - \\
& Moderate & - & - \\
& High & 3 & 5.2 \\
& Very high & 55 & 94.8 \\
& No risk & - & - \\
Last DH* & Low & 7 & 12.1 \\
& Moderate & 11 & 18.9 \\
& High & 22 & 37.9 \\
& Very high & 18 & 31.1 \\
\hline
\end{tabular}

*It includes discharge or death. If the patient was not assessed before discharge or death, the score from the last evaluation was repeated.

Table 4. Place of involvement and stage of development of pressure injuries (PI) $(n=17)$ in patients of the Intensive Care Unit. Cascavel, Paraná, Brazil, 2016.

\begin{tabular}{|c|c|c|c|}
\hline Variable & Categorias & $n$ & $\%$ \\
\hline \multirow{4}{*}{ PI Place } & Face & 1 & 5.9 \\
\hline & Scapulas & 2 & 11.7 \\
\hline & Breasts & 1 & 5.9 \\
\hline & Sacral & 13 & 76.5 \\
\hline \multirow{4}{*}{ PI Stage } & I & 4 & 23.5 \\
\hline & $\|$ & 10 & 58.9 \\
\hline & III & 3 & 17.6 \\
\hline & $\mathrm{VI}$ & - & 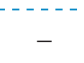 \\
\hline
\end{tabular}




\section{DISCUSSION}

The sample investigated was predominantly men, with a mean age of 50 years. Regarding gender, this data corroborates with several other studies realized on the ICU clientele, both in Brazi1 ${ }^{6,8,13}$ and in other international realities and care contexts, to the example of a study with the inclusion of 12 hospitals in China ${ }^{17}$, in addition to of a meta-analysis of researchers in Iran who stated that the incidence of PI in the postoperative period is related to the men ${ }^{18}$.

Another recent study identified that there is a statistically significant association between male gender and the development of PI in an ICU for patients with cardiac and respiratory diseases ${ }^{11}$. Regarding this, it is noticed that the clinical profile of the sample of this research possibly returned to the surgical treatment, since the greater part of the bases for the medical diagnosis of hospitalization in the ICU was related to trauma and to neurological problems (Table 1). Thus, this is probably related to the very profile of the investigated hospital, which is a reference for trauma, which, not infrequently, includes neurosurgery in interventions to the polytraumatized patient.

The mean age of the patients contrasts with a similar study in which $85 \%$ of the intensive care clientele were more than 60 years of age ${ }^{13}$. Again, the fact that the hospitalization profile of the sample investigated was not mainly of clinical order, that is, the common profile of the elderly population in the hospital system. Therefore, it is interpreted that the largest portion of the patients served in the service was not elderly, they were treated in the ICU due to trauma and external causes, which may have also reflected in the average length of stay in the ICU lower than other studies, in which the mean age of the patients was higher ${ }^{10,13}$.

Regarding the conditions and clinical interventions predisposing to $\mathrm{PI}$, the expected data, due to the investigated context (ICU), were: high proportion of sedative patients (84.4\%), vasoactive drugs (77.5\%) and mechanical ventilation (91.3\%). Due to the very characteristic of intensive care, these are common interventions for ICU treatment, which is known to assist severely ill patients in the primary purpose of maintaining favorable conditions for life. That said, it is considered elementary that the health team be prepared to harmonically attend the needs of clinical-therapeutic interventions associated with the prevention of iatrogenics common in ICU, such as PI and ventilator-associated pneumonia ${ }^{7}$.

Regarding the use of vasoactive drugs, this is a factor that deserves special attention from the nursing team, in charge of direct patient care. This is because, this pharmacological intervention can often be accompanied by hemodynamic instability of the patient, which, as a consequence, may become a factor of contraindication to bed movement, which is one of the main measures of PI prevention ${ }^{1,3}$.

The nurse, as care manager, together with the health team should be attentive to the individualized assistance in the search for alternatives that are able to minimize the pressure if the patient cannot be moved frequently. In this sense, strategies have been oriented such as the use of protective materials/devices previously positioned to the appearance of any sign of injury in the bony prominences; the maximal and controlled search for the redistribution of the patient's body pressure against the bed; in addition, if possible, the use of special mattresses with dynamic air movement ${ }^{3,19}$.

Regarding the extrinsic risk factors to the patient of PI development, all of them used air mattresses associated (overlaid) with traditional hospital mattresses. This is a positive factor of the place searched, since the use of these devices at the expense of the use of the common mattress is considered a protective factor ${ }^{13}$.

A study ${ }^{14}$ with the objective of evaluating the use of the mattress that made the scheduled redistributed insufflation and disinflation of compressed air in pockets in the reduction of PI in coronary units of a reference hospital in cardiology, showed a reduction of $55.4 \%$ in the overall rate of PI incidence in the period after hospital acquisition of the mattresses. Thus, this refers to the reflection that the prevention of PI, despite being essentially based on care, can be favored by the rational use of the technology available for care.

No patient had bedside elevation $>45$ degrees, which favors PI involvement, since the pressure in the sacral region, especially, can be greatly increased ${ }^{3,5}$. A 36.2\% rate of positioning was achieved at 30 to 45 degrees from the bedside, which, while not ideal for PI prevention, may be a measure adopted to mitigate the risk of other adverse events or complications, such as pneumonia associated with mechanical ventilation ${ }^{20}$. Therefore, the importance 
of the nurse to the health team is reinforced by making individualized, planned and continuously reassessed care possible, since the challenges faced in the treatment of critically ill patients are evident.

It is common and expected that patients newly admitted to the ICU present critical clinical conditions, which requires therapeutic interventions such as sedation, which exempts the level of consciousness and makes autonomous mobilization unfeasible, and therefore any capacity for self-care such as nutrition and body hygiene ${ }^{7}$. In this sense, the results of Table 3 demonstrate a high proportion (94.8\%) of extremely high PI risk measured by the Braden scale at admission, which, although not a clinical severity scale and/or sedation level, is distributed in variables of sensory perception, moisture, activity, mobility, nutrition and friction and shear ${ }^{15}$.

Still about Table 3, although it was necessary to repeat the Braden scale score from the last evaluation of some patients in the score of the day of their discharge and/ or death, the proportion of patients assessed as high and very high risk on the last day was more than half of the sample (69\%). This is a fact that denotes that PI, although more incident in $\mathrm{ICU}^{4}$, is not a problem exclusive to this sector, that is, non-critical or semi-critical hospitalization units also need to be attentive to the search for reduction of incidence of the event and their preventive measures, since they receive the patient before being admitted to the ICU, still at risk for the offense.

The observed incidence rate of PI was $20.6 \%$. This discovery, by itself, is extremely valuable to the context investigated and possibly the PI knowledge construct because it allows for internal and external comparisons in order to establish more assertive goals for improvement. In this aspect, the incidence was slightly lower than that of a study realized in an ICU in Vitoria, Espirito Santo, which determined the rate in $22 \%^{10}$; to another study realized in two units of the same scope in Natal, which identified a 50\% incidence in the observation of 40 intensive care patients ${ }^{13}$; and was also lower than a study conducted in three hospitals in the state of Mato Grosso, which found the incidence of the event between $25 \%$ and $66.6 \%{ }^{12}$. Also, also in the context of a public hospital ICU, another study showed a higher incidence $(37.03 \%)$ than that presented in this ${ }^{21}$.

Despite the above, the incidence of this study was higher than that of the study ${ }^{22}$ performed in the ICU in the countryside of São Paulo, which defined the rate as
13.95\%; and another study that found an incidence of $11.0 \%$ in the city of São Paulo in a cardiopneumological $\mathrm{ICU}^{11}$. In addition, the incidence found in this study was also higher than double the average result $(10.1 \%)$ of the survey, also in São Paulo, with the participation of three teaching hospitals ${ }^{9}$. However, it should be noted that the study cited did not include ICU in its sample, so it may not be considered a reliable standard of comparison, but it certainly can be interpreted as a north for improvement.

The comparison of internal or external assistance results to the institutions is a difficulty among researchers, managers and health professionals. In this regard, the Commitment with the Hospital Quality (CHQ) program establishes a methodology for the evaluation and certification of hospitals that voluntarily adhere to it and, among other actions, allows comparison/benchmarking between institutions of the same size or type of care ${ }^{16,23}$.

In the context of PI in ICU, the first monthly evaluation report of the year 2015 of hospitals adhering to the CHQ for the event incidence indicator resulted in a maximum of $26.53 \%{ }^{23}$, that is, a value higher than that found in the study. Although this data was the result of a shorter time of observation than the present research, it is postulated that what is most interesting is the fact that the possibility of knowing other assistance results, favoring decision-making in search of quality and patient safety. Thus, this could favor the establishment of feasible goals and the elaboration of standards on the involvement of PI in ICU and beyond.

Regarding the location of injuries in the sample (Table 4), he highest concentration (76.5\%) of PI in the sacral region is an aspect of wide agreement in the literature ${ }^{8,10-13}$. In addition to the fact that the second largest portion of PI involvement occurred in the scapular region of the patients, it can be inferred that the skin care of the back, although not exclusive, should be a factor of attention to the health team and, mainly of nursing of the ICU researched.

On the developmental stage of PI, the highest concentration was in stage II (Table 4). This can be a worrying factor if it is interpreted as a difficulty for the team to diagnose previously the signs of persistent hyperemia of the first stage ${ }^{5}$. In spite of this, it is also necessary to reflect that $\mathrm{PI}$ is a rapidly evolving clinical wound ${ }^{3}$, therefore, there is no pre-judgment here, but rather the frankness that PI is undoubtedly a problem to be faced with persistence and seriousness by the health team, with special emphasis on those who provide intensive care. 
The above-mentioned fact points to the importance that hospital managers need to demand from the nursing team, since this professional category, even in the context of intensive care, may have the work overload - commonly associated with the caregiver's human capital deficit related to the higher risk of development of adverse events, such as $\mathrm{PI}^{24}$.

It is known that the ICU investigated still does not have the $\mathrm{PI}^{1}$ prevention protocol implanted in the care dynamics, in which the preventive actions, although existent, occur in an unsystematic way. With this, it is considered that post-implantation studies of the patient's safety device will certainly be an important perspective towards improving the quality of care and the search for evidence-based practice.

\section{CONCLUSION}

It was concluded that the incidence of PI in the ICU was $20.6 \%$, and the characteristics of the event show a welldefined profile, with emphasis on: predominance of male patients; hospitalized in the ICU for neurological causes and trauma; presence of several intrinsic risk factors to the developed PI; and injuries more affected in the sacral region and stage II. With the incidence identified and the risk profile well delimited, actions to prevent PI can be (re)planned.
Once the risk factors for the adverse event have been recognized, it is well known that ICU patients need vigilant attention from the health team, in order to mitigate the risk of PI development, inclusively. Added to this, it is evident that the nursing team, which is based on human care and, obviously, not isolated and with favorable working conditions, deserves to lead the actions of search for patient safety, including those hospitalized in ICU.

It is believed that the most obvious limitation of this research is its purely descriptive character, that is, the impossibility of generalizing its results and determining associations between variables. Despite this, it is postulated that the study contributes greatly to the amount of PI knowledge and, in parallel, to the search for safe care, since its discoveries can strengthen decision making for measures that converge to the quality of the patient's care severely sick.

\section{AUTHOR'S CONTRIBUTION}

Conceptualization, Constantin AG; Moreira APP; Hofstätter LM; Oliveira JLC and Fernandes LM; Methodology, Constantin AG; Oliveira JLC and Fernandes; Investigation, Constantin AG; Moreira APP e Fernandes LM; Writing - Original Draft, Constantin AG; Moreira APP; Hofstätter LM; Oliveira JLC and Fernandes LM; Writing - Review \& Editing, Constantin AG; Moreira APP; Hofstätter LM; Oliveira JLC and Fernandes LM.

\section{REFERENCES}

1. Brasil/Ministério da Saúde, Agência Nacional de Vigilância Sanitária, Fundação Oswaldo Cruz. Anexo 02: Protocolo para prevenção de úlcera por pressão. Brasília, DF: ANVISA; 2013.

2. Tres DP, Oliveira JLC, Vituri DW, Alves SR, Rigo DFH, Nicola AL. Qualidade da assistência e segurança do paciente: avaliação por indicadores. Cogitare Enferm. 2016;21(5):1-8. doi: 10.5380/ce.v21i5.44938.

3. National Pressure Ulcer Advisory Panel, European Pressure Ulcer Advisory Panel, Pan Pacific Pressure Injury Alliance. Prevention and treatment of pressure ulcers: quick reference guide. Perth: Cambridge Media; 2014.

4. Associação Brasileira de Estomaterapia, Associação Brasileira de Enfermagem em Dermatologia, Caliri MHL, Santos VLCG, Mandelbaum MHS, Costa IG. Classificação das lesões por pressão - consenso NPUAP 2016 - Adaptada culturalmente para o Brasil [Internet]. [cited in 20 jan. 2017]. Available at: http://www.sobest.org.br/textod/35

5. Efteli EU, Gunes UY. A prospective, descriptive study of risk factors related to pressure ulcer development among patients in intensive care units. Ostomy Wound Manage. 2013;59(7):22-7.

6. Sousa Júnior BS, Silva CC, Duarte FHS, Mendonça AEO, Dantas DV. Análise das ações preventivas de úlceras por pressão por meio da escala de Braden. ESTIMA, Braz. J. Enterostomal Ther. 2017;15(1):10-8. doi: 10.5327/z18063144201700010003.

7. Stein EA, Santos JLG, Pestana AL, Guerra ST, Prochnow AG, Erdmann AL. Ações dos enfermeiros na gerência do cuidado para prevenção de úlceras por pressão em unidade de terapia intensiva. Rev Pesq Cuid Fundam. 2012;4(2):2605-12.

8. Fernandes LM, Silva L, Oliveira JLC, Souza VS, Nicola AL. Association between pressure injury prediction and biochemical markers. Rev Rene. 2016;17(4):490-7. doi: 10.15253/2175-6783.2016000400008.

9. Melleiro MM, Tronchin DMR, Baptista CMC, Braga AT, Paulino A, Kurcgant P. Indicadores de prevalência de úlcera por pressão e incidência de queda de paciente em hospitais de ensino do município de São Paulo. Rev Esc 
Enferm USP. 2015;49(Esp2):55-9. doi: 10.1590/s0080623420150000800008.

10. Borghardt AT, Prado TN, Bicudo SDS, Castro DS, Bringuente MEO. Úlcera por pressão em pacientes críticos: incidência e fatores associados. Rev Bras Enferm. 2016;69(3):460-7. doi: 10.1590/0034-7167.2016690307i.

11. Campanili TCGF, Santos VLCG, Strazzieri-Pulido KC, Thomaz PBM, Nogueira PC. Incidência de úlceras por pressão em pacientes de Unidade de Terapia Intensiva Cardiopneumológica. Rev Esc Enferm USP. 2015;49(Esp):714. doi: 10.1590/s0080-623420150000700002.

12. Costa IG. Incidência de úlcera por pressão em hospitais regionais de Mato Grosso, Brasil. Rev Gaúcha Enferm (Online). 2010;31(4):693-700. doi: 10.1590/S1983-144720 10000400012.

13. Fernandes NCS, Torres GV, Vieira D. Fatores de risco e condições predisponentes para úlcera de pressão em pacientes de terapia intensiva. Rev Eletr Enferm. 2008;10(3):733-46. doi: 10.5216/ree.v10.46624.

14. Pinho CM, Correia RN, Valença MP, Cavalcanti ATA, Gomes ET. Uso do colchão pneumático na redução de úlceras por pressão: eficácia e percepções da enfermagem. Rev Enferm UFPE (Online). 2014;8(8):2729-35.

15. Serpa LF, Santos, VLCG, Campanili TCGF, Queiroz M. Predictive validity of the Braden scale for pressure ulcer risk in critical care patients. Rev. Latino-Am. Enfermagem. 2011;19(1):50-7. doi: 10.1590/S0104-11692011000100008.

16. Núcleo de Apoio à Gestão Hospitalar, Compromisso com a Qualidade Hospitalar. Manual de indicadores de enfermagem NAGEH/Compromisso com a Qualidade Hospitalar (CQH). 2a ed. São Paulo: APM/CREMESP; 2012.
17. Jiang Q, Li X, Qu X, Liu Y, Zhang L, Su C, et al. The incidence, risk factors, and characteristics of pressure ulcers in hospitalized patients in China. Int J Clin Exp Pathol. 2014;7(5):2587-94.

18. Shafipour V, Ramezanpour E, Gorji MAH, Moosazadeh M. Prevalence of postoperative pressure ulcer: a systematic review and meta-analysis. Electronic Physician. 2016;8(11):3170-6. doi: 10.19082/3170.

19. Olkoski E, Assis GM. Aplicação de medidas de prevenção para úlceras por pressão pela equipe de enfermagem antes e após uma campanha educativa. Esc Anna Nery. 2016;20(2):363-9. doi: 10.5935/1414-8145.20160050.

20. Silva SG, Nascimento ERP, Salles RK. Bundle de prevenção da pneumonia associada à ventilação mecânica: uma construção coletiva. Texto Contexto Enferm. 2012;21(4): 837-44. doi: 10.1590/s0104-07072012000400014.

21. Matos LS, Duarte NLV, Minetto RC. Incidência e prevalência de úlcera por pressão no CTI de um hospital público do DF. Rev Eletr Enf. 2010;12(4):719-26. doi: 10.5216/ree. V12i4.8481.

22. Palhares VC, Palhares Neto AA. Prevalence and incidence of pressure ulcers in an intensive care unit. Rev Enferm UFPE (Online). 2014;8(Suppl. 2):3647-53.

23. Compromisso com a Qualidade Hospitalar. Comparativo de indicadores hospitalares [Internet]. 2015 [cited in 20 jan. 2017]. Available at: http://www.cqh.org.br/icqh/estat/ind/ web_ind.php

24. Cremasco MF, Wenzel F, Zanei SSV, Whitaker IY. Pressure ulcers in the intensive care unit: the relationship between nursing workload, illness severity and pressure ulcer risk. J Clin Nurs. 2012;22(15-16):2183-91. doi: 10.1111/j.13652702.2012.04216.x. 